\title{
Disclosing the Hidden: The Narration of Thoughts in Bessie Head's Maru
}

\section{Khadidiatou Diallo}

\section{(2) OpenEdition \\ 1 Journals}

Electronic version

URL: https://journals.openedition.org/ces/5474

DOI: $10.4000 /$ ces.5474

ISSN: 2534-6695

\section{Publisher}

SEPC (Société d'études des pays du Commonwealth)

\section{Printed version}

Date of publication: 1 April 2012

Number of pages: $31-42$

ISSN: 2270-0633

\section{Electronic reference}

Khadidiatou Diallo, "Disclosing the Hidden: The Narration of Thoughts in Bessie Head's Maru", Commonwealth Essays and Studies [Online], 34.2 | 2012, Online since 19 April 2021, connection on 23 July 2021. URL: http://journals.openedition.org/ces/5474 ; DOI: https://doi.org/10.4000/ces.5474

\section{(c) $($ () $\ominus$}

Commonwealth Essays and Studies is licensed under a Licence Creative Commons Attribution - Pas d'Utilisation Commerciale - Pas de Modification 4.0 International. 


\section{Disclosing the Hidden: The Narration of Thoughts in Bessie Head's Maru}

This article conjugates Dorrit Cohn's postulates on the representation of the mind in a narrative work with Bakhtin's argument on how action and the many voices in a novel are ideologically-determined to reappraise the psychological dimension of the story in Bessie Head's Maru. It demonstrates that the characters' intense mental discourse and psychic interactions are a scathing indictment of prejudice and tribal/racial discrimination and also a way for the author to speak out her aspiration for a more humane world.

The novel as a whole is a phenomenon multiform in style and variform in speech and voice.

Bakhtin, The Dialogic Imagination 261

The life story of Bessie Head reads like an epitome of South Africa's history. As a person of mixed ancestry, a "Coloured" according to the racial terminology used under apartheid, Head stood at the crossroads of two populations, Blacks and Whites, who remained at loggerheads for the duration of apartheid. Coloureds and Blacks were marginalized by the racist regime which progressively transformed South Africa into a place where people were, according to Head, "living with permanent nervous tension" (A Question of Power 19). Her experience of racism and social rejection is shared by the main figures of her books. Two orientations mark her literary output: first, we have "inwardly-directed" novels, later to be followed by "socially-oriented" works (Mackenzie 19). Her three first novels - When Rain Clouds Gather, Maru, and A Question of Power - "share a basic quest pattern, which moves in a suggestive direction" (Wilhem 8). Her literary works put "growing stress on the psychic arena, on the struggle for human soul by contending forces" (Mackenzie 19).

Maru is the novel that features the most extensive representations of inner and outer life. Characters in the novel intensively reflect upon the construction, contradictions and unfairness of their social world: "Head employs the schizophrenic construct and the figure of irony in the representation of ambiguities, polyphonies, binaries, and the misrecognition of the manifest and the concealed in a post-colonial Botswana setting" (Olaogun, "Irony" 73). The characters exchange on these issues and deliver monologues that give the reader access to their minds, revealing what they are thinking and how their minds work. This intrusion into the psychic arena is narrated through the categories of direct, indirect and free indirect speeches, which Dorrit Cohn respectively calls "monologue," "narrated monologue," and "psycho-narration." In an exhaustive analysis, Cohn explains the functioning and representation of characters' thoughts in narrative and accounts for the contribution of thought representation to the narrative coherence of a literary work. In Maru, figures like the eponymous character muse over the social and cultural realities of their community mainly through psycho-narrations and narrated monologues that read like a "deliberate examination of the reasons for the 
low social status of the San, ${ }^{1}$ or the Batswana, alias Bushmen, in Botswana, and how the causes of this low status manifest local and universal patterns of slavery" (Olaogun, "Slavery" 181).

This essay analyses how the narrative voice delineates the psychological impact of tribalism on the characters and explains how "symbolic and complementary characterization develops and inner lives interact to promote external change" (Phillips 97). In Maru, the manner in which Head advocates change occurs in monologues but also through internal voices dialoging and sometimes colliding on the socio-cultural organization in Dilepe village. In his analysis of the dialogical properties of the novel, Mikhail Bakhtin contends that the "action and individual act of a character in a novel are essential in order to expose - as well as to test - his ideological position, his discourse. [...] He has his own perception of the world that is incarnated in his action and in his discourse" (334-5). This assertion is relevant to Maru in which the reporting of thoughts unveils the characters' reactions to weighing external forces and their aspirations for change. Cohn's own approach in Transparent Minds complements Bakhtin's insofar as she adopts the perspective of psychoanalysis to understand how fiction addresses the stifling social factors that shape characters' minds and prompt their inner reflections. As a result, this article conjugates Dorrit Cohn's postulates on the representation of the mind in narrative works with Bakhtin's argument on how action and the many voices in a novel are ideologically-determined, in order to analyze the different types of monologues found in Maru, in addition to the structural mechanisms that underpin their insertion in the narration. Ultimately, it demonstrates the contribution of these "hybrid constructions"2 (Bakhtin 334) to Head's denunciation of tribal prejudices.

In Maru, the story abounds in sustained descriptions of free indirect discourses, a technique that Dorrit Cohn calls "psycho-narration" (21). In a psycho-narration, words or thoughts "are not really reported to the reader, they are merely summed up by the narrator who is foregrounded" (Hughes \& Patin 104). In Head's novel, the narrator, through comments, monitors and conveys the overdrive of thoughts from characters like Maru, Moleka, Dikeledi and Margaret Cadmore, who all ponder over the dysfunction of their prejudice-laden society. Psycho-narration and narrated monologue are mostly used in Maru. They are devices that make the minds of members of the narrative personnel more transparent. Such a transparency reveals the dissonance between Maru's dreams, his aspirations, and the social fabric of the Batswana community. There are multiple instances of the unfolding of thoughts bearing the imprint of the narrative voice.

At the outset of the story, the astonishment of Margaret Cadmore senior (the wife of the white missionary), about the brutality and backwardness of the Batswana's cultural beliefs is expressed in a long psycho-narration:

1. In Botswana, the Bushmen, also called the Masarwa, were kept as slaves, and considered the lowest of the low. Bessie Head, in Maru, takes this situation as a pretext to denounce all forms of oppression based on tribe or race, as was the case in South Africa during Apartheid.

2. The phrase "hybrid constructions" refers to utterances from two or more linguistic systems which, according to Bakhtin, cannot be grammatically separated. Bessie Head's prose is fraught with hybrid or double-voiced speeches - quoted, narrated monologues and psycho-narrations - that are strongly determined by external contending forces. Theorists of postcolonialism, like Homi Bhabha in The Location of Culture, have given a critical appraisal of the concept, showing that hybridity challenges essentialism. Cultural hybridity has been associated to sociological theories of identity, racism and multiculturalism. 
It is preferable to change the world on the basis of love of mankind. But if that quality be too rare, then common sense seems the next best thing. [...] and it was the simplicity of her approach and arguments that created the impression that she could open any door, make the contents within coherent, and that she stood for all that was the epitome of human freedom. Good sense and logical arguments would never be the sole solution to the difficulties the child would later encounter, but they would create a dedicated scholar and enable the child to gain control over the only part of life that would be hers, her mind and soul. She would have to take them and apply them to the experiences gained in a hostile and cruel society. They would mean the capacity, within herself, to survive both heaven and hell. (12-6)

This comment on Cadmore's interiority sets the tone of the events of the story. Mrs Cadmore muses upon the tragic fate awaiting the child she is rearing, the orphan daughter of a wretched Masarwa woman who died giving birth. In the Batswana society, Masarwa are pegged as "niggers," a term of contempt which means a low and filthy person (12). The passage opens with a pronounced narratorial comment which bears didactic overtones: "indeed in such a society where some section of the community is browbeaten, trodden down and enslaved by supercilious people, there is a great need to reshuffle the social and moral order on the basis of love of mankind or at least of common sense" (13). This ideal vision of human relationships seems utopian in the society described in Maru, where even common sense is lacking and where people are trapped in stereotypical beliefs.

The syntactic and verbal contours of this "bare report" (McHale 278) are the devices that signal the psycho-narration right away. Cadmore's mental activity is pinpointed here by the reproachful tone conveyed through the nature of the discourse. With verbs suggesting mental operations, "that created the impression... she could...", but also with the backshifting in the tense system - the repetitive use of the conditional auxiliary "would" indicating the presence of the narrator - combined with a gamut of dysphoric adjectives ("hostile.... cruel society") through which Cadmore makes a value judgement of the society, there is a hint at the atrocities and arbitrariness bred by stereotypes and prejudices. These stylistic cues make the representation of her inner life "a sounding board for general truths about human nature" (Cohn 23). The truths unfolded in this first insight into Cadmore's mind are much more suggested in this second interior monologue, after a severe rebuke of the pupils who have been harassing the young Masarwa child Cadmore has named after her:

Allowance had to be made for all living beings. An allowance for life had always been made for really vicious people, who for too long had said the kind of things to helpless people which really applied to their own twisted, perverted hearts. Those who spat at what they thought was inferior were really the low filthy people of the earth, because decent people cannot behave that way. (19)

Apart from the didactic style of the passage, the numerous appreciative adjectives clearly indicate that these are the character's own words carefully re-told by the narrator. These syntactic elements are a chiding of the distorted mind and of the oppressive attitudes of the community. According to Mackenzie, Maru is a "powerful indictment of racial prejudice wherever it is found" (14). By scorning the tribal oppression in Botswana, Head denounces the racial prejudice she and her fellows experienced in South Africa under apartheid. The use of the psycho-narration is relevant here because it allows the distant narrator to make a value judgement of the inner motives of Margaret Cadmore. 
The technique allows the narrator to present and comment on the feelings and thoughts of the characters by rendering their mental and psychological actions (Gardes-Tamine 72).

The representation of Cadmore's thoughts is fraught with satire. In fact, the missionary's wife is much more driven by her curiosity aroused by the cultural contradictions of the Batswana community, and by the girl whom she takes as an "experiment," than by humanitarian motives. This is first hinted at through the matter-of-fact and disheartening tone of her words towards the oppressed young girl: "They are wrong. You will have to live with your appearance for the rest of your life. There is nothing you can do to change it" (18). The hypocrisy of the missionary's wife is also suggested by the narrator's satirical expression of her thoughts and actions: "The old white-haired lady was retiring to England. There was still one term left before her 'experiment' passed out as a fully trained primary school teacher [...] The old plump lady pretended to cry, dabbing at dry eyes with a dry handkerchief" (19). The repetition of the adjective "dry" implies the fake sadness of the lady and symbolises the colonizers' responsibility in fostering prejudices through the aggravation of extant tribal and racial forms of discrimination in this part of Africa.

In Maru, psycho-narrations have another ultimate function in the commitment of Head to fight against any form of domination and oppression. They ensure the didactic contours of the story, instructing and alerting readers to the dangers of categorizing people in terms of race and tribal affiliations. Margaret Cadmore Jr - the Masarwa pupil and later teacher in Dilepe village, the backdrop of the novel's actions - suffers from the viciousness of a society where skin colour or tribal belonging determines people's social rank and reminds her that she and her likes are not part of them. And such a degrading attitude progressively causes the protagonist to sink into a state of acute marginalization. Like Head, she "remained a woman with a crippling legacy of loneliness and rejection, eking out an existence in a quiet corner of Africa" (Mackenzie 8).

When Margaret Cadmore Jr comes for the first time to Dilepe as a teacher, she openly admits to Dikeledi and Pete, the principal of the school to which she has just been transferred, that she is not a Coloured but a Masarwa. Her outspokenness shocks the principal:

The principal of the school belonged to that section of mankind which believed that a position demanded a number of exaggerated mannerisms. [...] Margaret's advance papers had aroused his curiosity considerably. Even the sight of her. He made the same error as Dikeledi, assuming she was a coloured. That was unusual too. Such children always worked in the shops of their white fathers. He thought he'd have something to talk about, such as that she must be the first of their kind to teach in their schools. He'd also have a sharp eye on racialism. Those types were well-known for thinking too much about their white parent, not about their African side. He eventually approached Margaret with his electric light smile. (39, italics in the original)

The "polyvocality" (McHale 284) of this part of the story comes from the joint use of psycho-narration and narrated monologue that Cohn defines as "the mental discourse of a character taken in charge by the narrative discourse" (29). She adds:

A typical narrated-monologue sentence stands grammatically between the two other forms, sharing with quoted monologue the expression of the principal clause, with psycho-narration, the tense system and the third person reference [...] in its meaning and functioning, as in its grammar, the narrated monologue holds a mid position between 
quoted narration and psycho-narration, rendering the content of a figural mind more obliquely than the former, more directly than the latter. Imitating the language a character uses when he talks to himself, it casts that language into the grammar a narrator uses in talking about him, thus superimposing two voices that are kept distant in the other two other forms. (29)

The superimposing or duality of voices is felt in the previous passage quoted from Maru. Like many of his counterparts, the principal is puzzled by Margaret Cadmore's light skin. Through the psycho-narration, the narrator digs out the biased views and prejudicial behaviours that Coloured people or Masarwa folks arouse among the community members. Mostly signalled by the short nominal structure "Even the sight of her" - which indicates that these are the words of the character - the psycho-narration highlights the racist and distorted mind of Pete who opines that children from mixed marriages are rarely in teaching. Such a viewpoint is further suggested through the narrated monologue introduced by the verbum dicendi "he thought" - which is one of the "cues in immediate context" (McHale 267) - and also by the use of the italics. The typography indicates a shift to the Principal's voice, as the italics report his thoughts by reproducing his mind style (Silva 18), but they also introduce a touch of irony in the representation by underlining the distance between the narrator and the character.

Therefore, by giving access to Pete's consciousness, the blend of psycho-narration and narrated monologue is an effective technique demonstrating to what extent stereotypes and racial discrimination have moulded the mind of Batswana, their situation recalling the biased ideas that were behind the racial dismemberment in South Africa under apartheid. Pete's shock and surprise at Margaret Cadmore's revelation are expressed in this covert polyvocal discourse: "The shock was so great that he almost jumped into the air. Why, he'd be the sensation of the high society circle, for a week! He controlled himself. He looked down. He smiled a little. Then he said 'I see"' (39). Pete is right to think that he and his school will be the laughing stock of the village, as people will neither understand nor accept that a member of the most loathed community should teach their offspring. Semantically, the narrated monologue is perceptible through the interjection "why," and also through the syntactic design of the sequence: the use of an exclamation mark suggests that the subject is utterly upset by the girl's reaction, an inner state the narrator has imitated, as it were, without altering the tense system and the third person reference.

Maru features numerous instances of discursive sections of the story cloaked in the grammatical contours of the third person narration that discloses the inner voices of some protagonists. Within the racially categorized society described in the novel, there are politically conscious characters who daily endeavour to improve racial/social relationships. Among them the sentient Dikeledi and Maru feel concern for the plight of the Masarwa. Together, and through different perspectives, they scrutinize the villagers' mindset in order to shun tribalism and encourage the development of a trans-ethnic society:

Maru raised one large hand and covered his face. He was laughing. He had a number of bombs to set off in the village of Dilepe. Some would explode soon, some a little later. This was the first time Moleka was out of it, and he was laughing because Moleka appeared just as much a fool as everyone else to his scheming and plotting. (60, my emphasis) 
This passage features a "double-accented, double-styled hybrid" construction (Bakhtin 305), introduced by the relation of a "fictional fact" as Maru, the chief to be, who holds Masarwa as slaves, is actually implementing his plot for the liberation of the latter. He knows that he must feign brutality towards the marginalized group until he has worked out his ambition. And one manoeuvre is to openly ill-treat the Masarwa teacher by taking back the bed Moleka gave her. The lexical cues in italics, the semantic aspect of the extract, the third-person style and tense structure combine to connote Maru's proximity with the narrator. Such complicity is apparent in the seamless joining of narrative comment in the first two sentences and the re-telling of the thoughts of the protagonist in what follows. Like the other villagers, Moleka is unaware of Maru's intention to dismantle the social and cultural organization of the village with his "bombs," as is suggested in the psycho-narration that closes the passage. Making transparent the character's mind is essential to the psychological dimension of the story because, as Mackenzie observes:

Clearly the storyline of Maru, the sequence of daily events, is simply a point of departure for Bessie Head; it is there to serve the needs of higher levels of meaning. It follows that the logic of this pattern of events is not one of externally-observable cause and effect. What gives coherence to events in Maru are the inner workings of the minds of the characters. The drama becomes internal; the subjects enter into relationship with each other at a psychic level. (26)

Maru and his sister are a good example of this intersubjective process because she is the one in whom he confides his dreams of marrying Margaret Cadmore, a marriage, he trusts, that will dismantle the stereotypes of the Batswana towards Masarwa, and foster the liberation of others like her. The feelings motivating Maru are discernible in the detailed representations of his inner thoughts:

He was almost tempted to expose Moleka and the real cause of his sudden suicide from Moleka the savage to Moleka the god. Who else made a god overnight but a goddess? [...] There was a world apart from petty human hatreds and petty human social codes and values where the human soul roamed free in all its splendour and glory. No barriers of race or creed or tribe hindered its activity. He had seen majestic kings of the soul, walking in the ragged clothes of filthy beggars. He could bring this home forcefully to her but the truth would destroy her and he needed her alive and stupid for his future plans. (67)

The structural pattern of the passage is almost the same as that of the previous examples from the novel; it starts with a psycho-narration followed by a narratorial expression of the character's thoughts. Maru is nourishing ideals for his society, dreams for more balanced and impartial interracial/intertribal connections. The mythic and symbolic dimension of the protagonist and his ability to roam into the heart, "the kingdom" of others confirms the words of Maggi Phillips about Head's fictional world: "The nurturing of dazzling inner worlds in unlikely climates is Bessie Head's most audacious achievement. Her central characters have cosmic dimensions: [...] Maru 'never doubt [s] the voices of the gods in his heart"' (93).

The structural aspect of the passage is rather revealing of Maru's motives. First, the narrator describes the intentions of Maru who is eager to explain to his sister the sudden change in her lover, Moleka. This is important because, as it precedes the narrated monologue, the psycho-narration is an effective means to assert the truth of Maru's words. The narrator allies himself with the character and reports his powerful ideas "in 
concealed form" (Bakhtin 303). The narrated monologue is signalled by the question mark, a syntactical clue which adds to the relevance of the quotation: "Who else made a god overnight but a goddess?" The rhetorical question insists on the power, beauty and humanity of Margaret Cadmore and all the down-trodden of her community hitherto denied by a society deeply seated in prejudice. The tone and the lexical cloak of the extract (notably with the repetition of the adjective "petty") further emphasizes the low and inhumane nature of Maru's people set against his dreamt world where "the human soul roamed free in all its splendour and glory." Such determination and faith in Maru's (and Bessie Head's) vision resound through the negative nominal structures found in the passage. This call for interracial brotherhood is foregrounded through the mimetic representation, i.e., the quoted narration of Maru's words:

"When you think of me." He said. "You think of me as they do [...] Three quarters of the people on this continent are like Morafi, Seth and Pete-greedy, grasping, back-biting, a betrayal of all the good in mankind. I was not born to rule this mess. If I have a place it is to pull down the old structures and create the new. Not for me any sovereignty over my fellow men. I'd remove the blood money, the cruelty and crookery from the top, but that's all. There's a section of my life they will never claim or own." (67-8)

Not only does Maru's language reflect his own vision of human relationships, in contrast with his society's, but it also articulates a human ambition in an inhuman social framework. It cannot be revealed to the villagers lest they be outraged, hence the narrator's choice of a concealed discourse.

Head's story in Maru, as well as in the rest of her fiction, castigates the irrational attitudes and absurdity behind some cultural organization through the characters' words and thoughts. This hankering for egalitarian social relationships is alluded to in Dikeledi's and Maru's juxtaposed monologues:

"Maru is a real chief. He is a little bit like the chiefs we had in the old days, before the white man arrived"

How was it then that he had inherited so much blood money and so many slaves whose only blanket was an outdoor fire? [...] Maybe he concentrated on his immediate situation. It was African. It was horrible. But whenever mankind had gathered itself together in a social order, the same things were happening. There was a mass of people with no humanity to whom another mass referred: "why, they are naturally like that. They like to live in such filth. They have been doing it for centuries."

Should he bother to explain to her the language of the voices of the gods who spoke of tomorrow? [...] People no longer needed chiefs and kings and figureheads who wore dazzling garments and ruled with the philosophy that there was never enough, so those who had had to put their foot down on those who had not? New kings were arising indeed. The stature and majesty would always be there, but the kings who arose now were those of the soul who could never betray their gods of goodness, compassion, justice and truth. The downtrodden were hearing the message of their humanity. Who could contain the fury of centuries of oppression and despising? (68-9)

The sequence opens with a quoted monologue, signalled by inverted commas, in which Dikeledi celebrates the grandeur of her brother, Maru. This is immediately followed by a pronounced comment on the thoughts that are bubbling up in the mind of the young woman who critically analyses Maru's outer behaviour, in line with that of Moleka, Sethe and others. Such critical interrogation is hinted at through assertive questions which paradoxically have an affirmative value. The narrated monologue bears 
semantic and grammatical signs that underpin the reproachful tone of the passage: Dikeledi virulently refers to the dysfunction of societies which seem to have a leaning for stereotyping and discrimination.

Likewise, in a Question of Power, Elizabeth wonders: "what did they gain, the power people, while they live off other people's souls like vultures? Did they seem to themselves to be the most supreme, most God-like, most wonderful, most cherished?" (19) Indeed, "Head additionally suggests in Maru that racial and ethnic bigotry comes from a universally expressed desire by one individual to dominate another" (Olaogun, "Slavery" 19). As such, Dikeledi's psycho-narration becomes "a sounding-board for a general truth about human nature," the harbinger of an ideology that promotes consciousness raising.

Dikeledi's analysis of the biased attitude of human beings extends into a broader generalization through Maru's inner voice, amplified as it is by the narrator. The narration of Maru's thoughts comes immediately after that of his sister, with no perceptible transition between them. The reader realizes how dense the mental activities of the two characters are; this is suggested through the juxtaposition of both discourses relayed by the narrator who seems to be concerned with the objects of such ponderings. Maru's indirect discourse presents almost the same textual markers, with a recurrent use of the interrogative, which is an effective way to dwell on the importance of racial equality, equity, justice and truth. Maru is distressed by the harsh treatment of the Bushmen by members of the society he is supposed to lead. But what they do not know is that he scorns such an attitude and refuses to become one of those despotic kings that have hitherto ruled over his community. Instead, his philosophy will be soon dominant, a hope reinforced by adverbs of insistence ("indeed," "always") and by the strong negation in "those who could never betray." Ultimately, Maru is convinced that the seething rebellion of the marginalized group can never be shunned, a conviction sharply expressed by the defiant question, "who could contain the fury of centuries of oppression and despising?" The narrator so identifies with Maru that he clears his language of any mocking or ironic effects (Joseph 79).

Thus, "Maru's quest is to attain the realm of the inner self, the being in touch with the secret pulse of the universe. He moves from the alienation of his tribal, exterior identity to his inner identity as a king of "heaven" (Mackenzie 26). In The Dialogic Imagination, Bakhtin argues that, in a novel, the speaking person (or thinking person in Maru's case) is an "ideologue" whose words are always "ideologemes" (333). Put differently, any discourse (speech or thought) reflects a particular way of viewing the world. Maru's inner discourse reveals his own perception of his society; his thoughts preach for the recognition of the value of the human soul and fight against any categorization of people based on race and tribe.

Throughout the story, Maru's actions, either towards Dikeledi, Moleka or Margaret Cadmore, reveal or test his ideological position. His moves to marry the Masarwa teacher, and thus to spark off the social liberation of her kind, echoing Bessie Head's position when she asserts that she uses whatever hopeful issue offered to her to shape a future built on dignity and compassion (Cray 99).

In her desire to build a more humane future for mankind, Head inscribes the heartwrenching situation of those who have been excluded from society. Through painstaking descriptions and sometimes allegory and hyperbole, the novel exposes the dull 
existence of the crestfallen girl in Dilepe. Quarantined as she is, Margaret is psychologically affected by the unjust social environment:

The rhythm of sunrise, the rhythm of sunset, filled her life. In the distance, a village proceeded with its own life but she knew not what it was - who married, who died, who gave birth to children [...] She was not a part of it and belonged nowhere. In fact, so quiet and insignificant were her movements that the people of Dilepe village almost forgot that there was such a thing as a Masarwa teacher. Now and then she caught their eye on her way to the shops or to school. They would laugh a bit, turn each other and say: "There goes the friend of Mistress Dikeledi." She had no life outside those words. (93)

The opening asyndeton suggests the humdrum and back-breaking life of the character who is neither involved in the life of the village nor respected by the villagers. As a consequence, Margaret Cadmore becomes more and more shut-in, silenced, to the point of being insignificant in the eyes of the villagers. Her social situation breeds resignation, as she is convinced that society will never allow her to live up to her dreams of mutual love: "She thought: 'He will never approach me, because I am a Masarwa' and it was something her whole way of life had prepared her for" (94). In this quoted monologue, the reader can feel the suffering the intolerance of her society caused the young woman. The direct quoting of Margaret's thoughts emphasizes her predicament. This attitude should be read more as a desire to keep distance from the girl than as a way to let her better express the loneliness caused by her being ostracized.

Margaret turns inward and takes up painting as therapy to express her hushed voice, and as "a defence against a hostile society. Her art becomes one of the inner resources with which she can cope with life" (Mackenzie 27). Her paintings are an inner discourse imparting, through Maru, that the Masarwa are endowed with craft, power and humanity. In the passage below, Maru becomes convinced of the validity of his ideals of equality and change as he decodes Margaret Cadmore's artistic language:

Maru took in the whole range and depth of the pictures. It was as though he had fallen upon a kind of music that would never grow stale on the ear but would add continually to the awakening perfection in his own heart. She chose her themes from ordinary, common happenings in the village as though those themes were the best expression of her own vitality. [...] They carried a message to his own heart: Look! Don't you see! We are the people who have the strength to build a new world! And his heart agreed. [...] It was as though, once she knew everything and had uncovered her own worth, she would awaken and share her gifts with those who needed them. The portraits and sketches traced this unfolding of the soul. [...] Thus the message of the pictures went even deeper to his heart: "You see, it is I and my tribe who possess the true vitality of this country. You lost it when you sat down and let us clean your floors and rear your children and cattle. Now we want to be free of you and be busy with our own affairs." (107-9)

The psycho-narration opening the passage is signalled mostly by the adverbial phrase "as though" describing Maru's mental situation. The paintings subsequently take centre stage and become a resounding voice that expresses the condition of oppression of the Masarwa but also their determination to rise up and "run out into the sunlight" (127). Through the internal focalisation of Maru, the structure of the narrated monologue of the speaking paintings is an appraisal of the Bushmen's grandeur. They defy Maru and all his peers to dare deny their human abilities: “look! Don't you see! We are the people who have the strength to build a new world!" The exclamative design of the sentence, overlaid with emotive and "attitudinal meaning" (Huddleston 374), is by the yardstick of Margaret's unconscious desire to rehabilitate her tribe through her art, to make the 
village community understand that the discriminated Masarwa are the king-pin of the village's economic thriving and, therefore, they deserve more consideration. Indeed, "Margaret embodies the transforming artist, both to a multiple maternal inheritance of racial inferiority, spiritual superiority, and an anti-racial education" (Phillips 97). The paintings are, thus, a subtle way to present the character's true being. Maru takes heart from the works of art, which become an inducement to his revolutionary action, as they "give suffering a voice and an image" (Wilhelm 11).

The psychic interaction between Margaret and Maru, and to a larger extent between the oppressor and the oppressed through the medium of art, and the involvement of the narrator in this tacit conflict, have one ultimate goal: the arising of an environment in which "soul-power" will take over physical or tribal power, and man's action will no longer be driven by "any narrow enclosure or social order" (109). For a long time, Maru has been nourishing such dreams, dreams that can be regarded as an inner voice claiming justice and truth:

He liked his own dreams and visions. They created an atmosphere where not only he but all humanity could evolve. They stretched across every barrier and taboo and lovingly embraced the impossible. There was no such thing as a slave or any man as an object of pity. But while he looked ahead to such a world, he was no fool. The vicious, the selfish, the cruel - those too he saw, and their capacity for creating misery. Where he could he nailed them to the ground, but always alertly with no intention of becoming their victim. And he intended following his own heart without in any way becoming the victim of a stupid, senseless, cruel society into which he had been born. Hence his lies and evasions. (110)

The description of the character's mental activity is a board of cardinal values for a more humane society. The lexical aspects and the grammatical moulding of the passage (with negative structures such as "no such things") underpin the trans-ethnic visions of Maru that urge him to embrace the impossible, though he "never strays far from the reality that conditions and occasions the dream" (Garret). Maru's inner voice is echoed by that of Margaret, who, less conscious of her "soul power," entertains the dream of social blossoming she shares with her friend Dikeledi:

"I had a strange experience," she said slowly. "Each time I closed my eyes those pictures used to fill all the space inside my head. [...]There was a wide open sky and field. I saw the pitch black clouds envelop the sky, but when I looked at my feet the whole field was filled with yellow daisies. They stirred a little as though they were dancing. Their movement also created this effect of gently revolving light. The next moment I was surprised to find myself walking along a footpath between the lovely daisies. I looked up again and a little way ahead I saw two people embracing each other. I stared quite hard because they were difficult to see. Their forms were black like the house and the sky but, again, they were surrounded by this yellow light." (102)

Such a revelation, in the guise of a quoted monologue, is both symbolical and premonitory. The reader realizes that the girl and Maru are on the same quest path. The use of the quoted narration is relevant here because it allows the character, for the first time, to disclose by herself, the hitherto hidden experience. Maru and Margaret "used to dream the same dreams" (124), the former hankering for a world where racial/tribal barriers are trampled down, the latter seeing "two people embracing each other," in a yellow-enlightened framework, full of daisies. The yellow light is a symbol of the long-desired happiness and freedom that are looming ahead for Margaret and her Ma- 
sarwa brethrens. ${ }^{3}$ Thus, Maru's thoughts related by the narrator and Margaret's breaking silence and expressing her inner yearnings constitute a soul communication and communion between the two characters (and their two different worlds) who become the loadstars of Bessie Head's ideal world, a world full of hope "where the sun rose, new and new and new each day" (125).

Bessie Head's Maru is informed by conflicting mental discourses. The novel's protagonists are deeply sunk into consciousness, as their inner being is confronted with contending external forces. The analysis of hybrid narrative constructions has shown the recurrent use of psycho-narration and narrated monologue, with an omniscient narrator stepping in frequently to expose the tribalism prevailing in Dilepe, the prism Bessie Head chose to denounce the racism and discrimination policies that prevailed in South Africa. Though one can criticize the author for not being overtly politicallycommitted, her representation of the characters' interiority is a strong expression of the angst and violence aroused in Head. Through the representation of unjust social realities in the story, Bessie Head scorns the tribalism and racism on which the apartheid regime erected its "divide-and-rule" homeland policies. Maru demonstrates, on the one hand, the backlashes of a biased cultural order on the Masarwa community and, on the other, it reveals a strong will to change people's mentality. The narratological tools defined by Cohn and used in this analysis make it possible to lay bare the narrative strategies in Head's indictment of the stereotypical ideas and prejudicial actions towards marginalized groups in Botswana and in South Africa. In Maru, the representation of thoughts adds weight to the narrativity of the story and reinforces the author's aim "to moralize reality" (White 14). Our analysis of Head's novel sheds light on the symbolic weight of this narrative technique in suggesting the contending forces and voices in the story, voices that signal the characters' ideological stand. Ultimately, narrative transparency in Maru is a way for the conscious characters (and for Bessie Head) to eschew and stifle any oppressive move.

Khadidiatou Diallo

University Gaston Berger, Sénégal

\section{Works Cited}

Bakhtin, Mikhail. "Discourse in the Novel." The Dialogic Imagination. Ed. Michael Holquist. Trans. Caryl Emerson and Michael Holquist. Austin: U of Texas P, 1981. 259-422.

BнавнA, Homi. The Location of Culture. London: Routledge, 1994.

CoHn, Dorrit. Transparent Minds: Narrative Modes for Presenting Consciousness in Fiction. Princeton: Princeton UP, 1978.

CONROY, Ellen. The Symbolism of Colour. 8 April 2021. <www.archive.org/stream/symbolismofcolour_ djvu>.

Cray, Stephen. "Bessie Head's End.” Review Essay. English in Africa 18.2 (October 1991): 99-105.

Gardes-TAmine, Joelle. La stylistique. Paris: Armand Colin, 1997.

Garret, James. "Writing Community: Bessie Head and the Politics of Narrative." October 2010 $<$ http://muse.jhu.edu $>$.

Head, Bessie. When Rain Clouds Gather. London: Heinemann, 1987.

—. A Question of Power. London: Heinemann, 1974.

3. "Yellow is the colour of the sun, all the attributes of the sun were given to it [...]. Yellow was said to be the colour of unity - unity in affection, unity with the spiritual power of the universe" (Conroy 15). 
HudDleston, Rodney. Introduction to the Grammar of English. Cambridge: Cambridge UP, 1984.

Hughes, Terence, and Claire Patin. L'analyse textuelle en anglais, Narrative Theory, Textual Practice. Paris: Dunod, 1998.

Joseph, George. "Free Indirect Discourse in Soleils des Indépendances." The American Journal of Semiotics 6.1 (1988-1989): 69-84.

Mackenzie, Craig. Bessie Head: An Introduction. Grahamstown: National English Literacy Museum, 1989.

McHale, Brian. "Free Indirect Discourse: A Survey of Recent Accounts." PTL 3.2. (April 1978): 249-87.

Nkosi, Lewis: Taskes and Masks: Themes and Styles of African Literature. Harlow: Longman, 1981.

Olaogun, Modupe. "Irony and Schizophrenia in Bessie Head's Maru." Research in African Literatures 25.4 (Winter 1994): 69-87.

-. "Slavery and Etiological Discourse in the Writing of Ama Ata Aidoo, Bessie Head, and Buchi, Emecheta."Research in African Literatures 33.2 (Summer 2002): 171-93.

Phillips, Maggi. "Engaging Dreams: Alternative Perspective on Flora Nwapa, Buchi Emecheta, Ama Ata Aidoo, Bessie head and Tsitsi Dangaremba's Writing." Research in African Literatures 25.4 (Winter 1994): 89-103.

Silva, Cibele. "The Representation of Thought in 'Circe': from James Joyce's Ulysses to Sean Walsh's Bloom." Belo Horizonte Faculdade de Letras da UFMG 2008. 8 April 2012.

<http://www.bibliotecadigital.ufmg.br/dspace/bitstream/1843/ECAP7J6H3T/1/text.pdf>.

White, Hayden. The Content of the Form. Baltimore: The John Hopkins UP, 1987.

Wilhelm, Cherry. "Bessie Head: The Face of Africa." English in Africa 10.1 (May 1983): 1-13. 